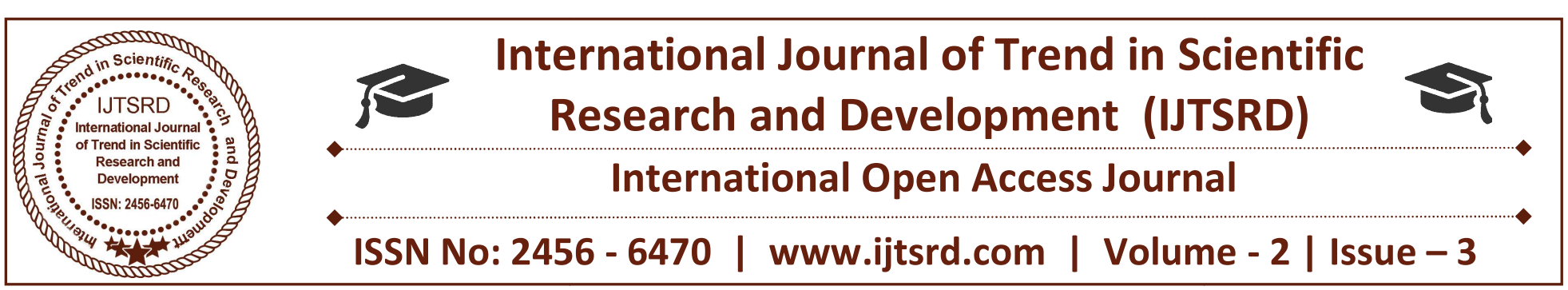

\title{
Diasporic Disorder in Amitav Ghosh's The Glass Palace
}

\author{
K. Shenbahapriya \\ MA., B.Ed., M.Phil, \\ Nadar Saraswathi College of Arts and Science, \\ Vadaputhupathi, Theni, Tamilnadu, India
}

\author{
R. Krishnaveni \\ MA English, \\ Nadar Saraswathi College of Arts and Science, \\ Vadaputhupathi, Theni, Tamilnadu, India
}

\section{ABSTRACT}

The term "diaspora" represents the general ideas of immigration. It is defined by forced dispersion caused by some sort of disaster. The spreading and preserve their identity from generation to generation. Diasporic live in one community but look across time and space to another. Diaspora takes the place of worry, and homelessness and it symbolizes a historical condition as well as state of mind. The word diaspora indicates the movement of a people away from an established or consequent development. The Glass Palace is an extraordinary achievement, a spectacular work of Amitav Ghosh.

Keywords: Diaspora, Migration, Refugees

\section{INTRODUCTION}

Diasporic disorder is the state in which the longings and yearnings of the immigrant is expressed. The longing is for the culture, people, human-relationship, and for the love and security that is offered by the native land. These longings and yearning of the immigrant psyche are expressed in all the genres of literature. Indian Diaspora is highlighted through the diasporic writers who have travelled from India to different and distant places. The word 'diaspora' refer to separating of the people and carries with it unclear status of being both an messenger and an immigrant. The use the word gives some of the ideologies, choices, reason symbol which may have governed the act of movement.

Amitav Ghosh was well-known and foremost expatriate writer, who goes to this genre expresses in his works, the sufferings and pains of the displaced people. Their disappointments, their loosening grip on life and their lives spent in a sorrowful longing for their roots can be seen as an elegy for the Diasporic disorder. The Glass Palace Amitav Ghosh vividly expresses the features of diasporic disorder. The diasporic condition in the novel succeeds due to the arrival of the royal power, which throws down Thebaw, the king of Burma after defeating his army in the battlefield. It is a saga of three generations that travel through Mandalay, to India and then finally to Malaysia. Colonialism had affected the life of both kings and the commoners .

Raj Kumar Raha, the protagonist of The Glass Palace was an eleven year old orphan boy from Chittagong caught in an alien land by an accident. In Burma a sense of 'belonging' develops in him and he decides to stay there. Being an Indian, he has to suffer greatly in this alien land. When Indian soldiers were marching toward the city, obeying the order of the local people and were attacked in their frenzy. The pathetic Diasporic condition by this incident:

Twisting Rajkumar's head around, he struck him across the face with the back of his fist. A spurt of blood shouts out Rajkumar's nose...

\section{- (The Glass Palace Page No.28-29)}

The sorrowful disorder of King Thebaw, Queen Supayalat, Princesses with their maids is disclosed when they had leave the royalty and were exiled to live in an alien land Ratnagiri. The person, who ruled the country once, has to live the life of a prisoner, far away from the land of his origin. It is ironic that the 
cruel queen, who had to leave the land of her reign and live a life of confinement, in an alien land, only for the love of her husband.

Dolly, the heroin of the novel is a faithful maid of Queen Supayalat, who too had to leave the land of her origin together with the royal family. She grew up in India and the idea of going back to Burma, threatens her. She is apprehensive of being called a foreigner in her own native land. Uma, the wife of the Collector, ask Dolly to leave the king and queen as she is not the prisoner of the British Empire, but Dolly's grief is clearly visible at the through of being treated as a stranger when she remarks:

If went to Burma now I would be a foreigner- they would call me Kalaa like they do Indians - a trespasser, an outsider from across the sea. I'd find that very hard, I think. I'd never be able to rid myself of the idea that I would have to leave again one day, just as I had to before. (The Glass Palace)

The thought of being twice displaced from their effects, intimidates the Diasporic people. This torturing state of Dolly was similar to that of Etta, in the novel A Backward Place by Ruth Prawer Jhabvala. Etta realises that it is not easy to reunites with the place in the same manner after a long gap: "she longed for Europe, it was true, and would do anything to get there, but she could no longer tackle it on her on". The self- inflicted act of dearth because of such displaced locations on the part of the colonised people who suffer from imaginary and unreal homeland is implicit in both Dolly and Rajkumar who assert their right in India, and Burma respectively to make their 'home'. In another incident when Rajkumar comes to India to marry Dolly, with whom he had fallen in love at first sight, Dolly refuses to marry him. She is completely taken up by the idea of her role as the caretaker of the royal family, especially with the first princess who is pregnant. Uma's liberal outlook and practical approach to life helps to convince Dolly, after which she marries Rajkumar.

The false identifications of the colonised subject with the immigrant were far more painful. The effect of mental settlement results in total battle in the relationship as in the case of District Collector, Beni Prasad Dey and his wife Uma Day. The Collector is copying the western code of conduct, keeps the Britishers above Indians and wants to be in the good books of the Britishers. While Uma, who plays the role of an graceful compere, leading a powered, and lonely life was unhappy in the stylish situation caused by her husband.

They have used to dream about the kind of marriage wanted.....To live with a woman as an equal, in spirit and intellect: this seemed to me the most wonderful thing life could offer. To discover together the world of literature, art: what could be richer, more fulfilling. (The Glass Palace 172-173)

Uma was not able to copy and more after the departure of Dolly, so she decides to leave her husband. And stay at her parent's home. Due to his false perception of identity the collector had to suffer and his suffering ends only with the end of his life. It is very painful to see people living under illusion about the exploitation of the Dias people. Another character in the novel Soya John also lives under the false idea of the Empire. He does not see the English as usurpers, he thinks that they are superior, and it is they who have taught him the art of using everything for his own benefit. It brings profit to him and he does not want to know anything beyond his immediate gain. Rajkumar too think like Saya and is convinced that without the British, the Burmese economy will breather.

In many cases, this Diasporic disorder contains a lot of confusion and anguish, and may take a turn for the worse. People who are not able to come to terms with the adverbs conditions of the displacement, lose their grip on life, and succumb under the pressure. Manju, Rajkumar's elder daughter-in-law is one such character was facing the needs of war and displacement commits suicides.

Throughout the narrative of The Glass Palace, Ghosh expresses the agonies and turmoils of the expatriates. "The expatriate being, expresses itself correct in a weight momentum". In all the works of Ghosh, find a continuous struggle to return to roots, on the part off the diasporic people, trying to overcome the exploitation and misery associated with their life. Ghosh's novels are in fact elegiac reminiscences of their sad dilemma. The Glass Palace is a sad song narrative the plight of the displaced.

\section{Conclusion}

The Glass Palace records the pictures of migrants, diaspora, refugees and exile people, their displacement, dislocation and state of mind. Diaspora was produced by the process, and colonization and postcolonial state making. Ghosh presents historical 
sense and sensibility of the King, the Queen, the Indian migration and refugees in their forced dispersion and migration in the wake of invasion of Burma. Ghosh's imagination is diasporic and is the product of specific histories of the subcontinent. Diaspora typifies the historical condition, the state of mind and takes the place of doubt and homelessness as in case of the Burmese royal family, Rajkumar, and Indian migrant in Burma.

\section{Bibliography}

> Jhabvala, Ruth Prawer, A Backward Palace. 1965; rpt. Harmondsworth; penguin, 1980

$>$ Ghosh, Amitav, The Glass Palace. New Delhi: Harper Collins Publisher India, 2000.

$>$ Margaret Gunning, The Glass Palace, Epic Under Glass. 13 February, 2011. 